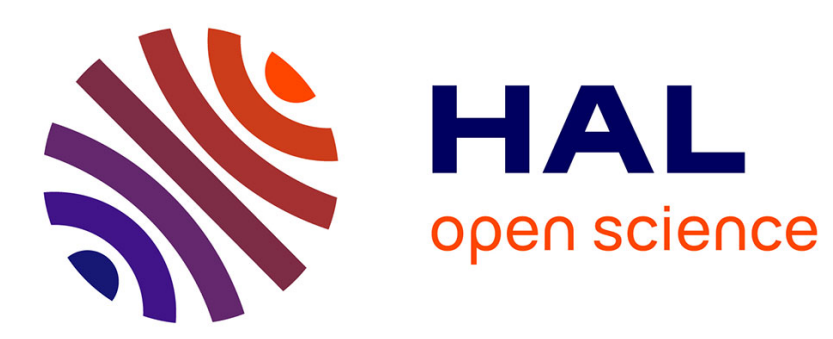

\title{
Influence of the dopants and of the microstructure on the ionic conductivity of zirconia
}

M. Filal, C. Petot, G. Petot-Ervas, M. Amamra, J. Carpentier, J. Dellis

\section{To cite this version:}

M. Filal, C. Petot, G. Petot-Ervas, M. Amamra, J. Carpentier, et al.. Influence of the dopants and of the microstructure on the ionic conductivity of zirconia. Journal de Physique IV Proceedings, 1993, 03 (C7), pp.C7-1463-C7-1466. 10.1051/jp4:19937228 . jpa-00251864

\section{HAL Id: jpa-00251864 https://hal.science/jpa-00251864}

Submitted on 1 Jan 1993

HAL is a multi-disciplinary open access archive for the deposit and dissemination of scientific research documents, whether they are published or not. The documents may come from teaching and research institutions in France or abroad, or from public or private research centers.
L'archive ouverte pluridisciplinaire HAL, est destinée au dépôt et à la diffusion de documents scientifiques de niveau recherche, publiés ou non, émanant des établissements d'enseignement et de recherche français ou étrangers, des laboratoires publics ou privés. 


\title{
Influence of the dopants and of the microstructure on the ionic conductivity of zirconia
}

\author{
M. FILAL, C. PETOT, G. PETOT-ERVAS, M.C. AMAMRA, J.L. CARPENTIER ${ }^{*}$ and \\ J.L. DELLIS*
}

CNRS, Université Paris XIII, 93430 Villetaneuse, France

* Université Amiens, Amiens, France

The electrical conductivity of monocristalline and polycristalline samples of yttria-doped zirconia was measured by impedance spectroscopy, in the temperature range $300-900^{\circ} \mathrm{C}$ and for oxygen partial pressures included between $10^{-24}$ and one atmosphere. Results show that the bulk conductivity is independent of the $\mathrm{PO} 2$ and varies with the amount of yttrium. The higher conductivities are obtained with zirconia samples doped with 9.5 moles \%. According to recent literature oxygen diffusion data, the results have been analysed taking into account the participation of different kinds of defects to the transport processes.

The grain boundary conductivity and the "composite effect" have been analysed taking into account microstructural characterizations. A maximum of ionic conductivity is observed with zirconia doped with 9.9 moles $\%$ yttrium when the amount of alumina is equal to approximatively 2 moles $\%$.

\section{EXPERIMENT RESULTS}

A-Yttrium doped zirconia single crystal : $\left(\mathrm{ZrO}_{2}(1-\mathrm{x}), \mathrm{Y}_{2} \mathrm{O}_{3}(\mathrm{x})\right)$.

$$
(\mathrm{x}=0.03,0.095,0.12,0.175) \text {. }
$$

\section{A 1 - Ionic conductivity}

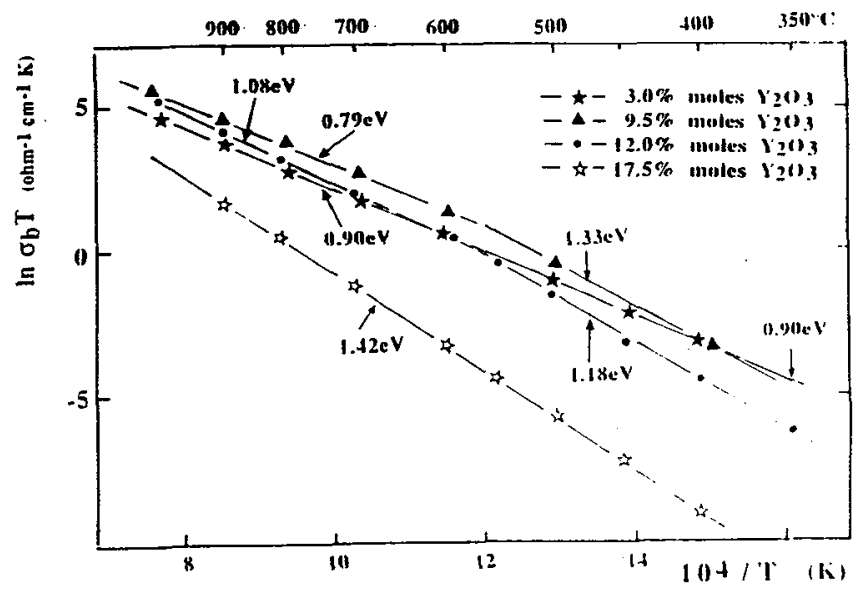

A break is observed on the bulk conductivity Arrhenius plot for the samples doped with 9.5 and 12 moles $\% \mathrm{Y}_{2} \mathrm{O}_{3}$.

Fig.1 : Bulk Conductivity.

\section{A-2 $\underline{\text { Discussion }}$}

For the samples doped with 9.5 and 12 moles\%. the results are in agreement with the literature data $(1-10)$, activation energy values we have obtained are, respectively :

$$
\mathrm{E}_{\mathrm{a}}=0.79 \text { and } 1.08 \mathrm{eV} \text { for } \mathrm{T}>560^{\circ} \mathrm{C}
$$


For the less ( 3 moles $\% \mathrm{Y}_{2} \mathrm{O}_{3}$ ) and higher doped samples ( 17.5 moles $\% \mathrm{Y}_{2} \mathrm{O}_{3}$ ), the activation energy is constant in all the temperature range. The values are closed to $\mathrm{E}_{\mathrm{a}}$ and to $\mathrm{E}_{\mathrm{b}}$ respectively .

The results obtained with the single crystal doped with 9.5 moles $\% \mathrm{Y}_{2} \mathrm{O}_{3}$ have been analysed taking into account oxygen diffusion coefficient values $\left(D_{O}\right)$ published recently $(8)$ and obtained with the same single crystal we have used. The ionic conductivity $(\sigma)$ is proportional to the diffusion coefficient of oxygen and can be written as follows :

$$
\sigma=\mathrm{e}_{\mathrm{O}^{--}}(\alpha \mathrm{e} / \mathrm{kT}) \mathrm{D}_{\mathrm{O}^{--}}
$$

where $\mathrm{n}_{\mathrm{O}^{--}}$is the number of ions per $\mathrm{cm}^{3}, \mathrm{D}_{\mathrm{O}^{--}}$is the diffusion coefficient of oxygen related to the experimental values $\left(D^{*} O\right)$ by the correlation factor $f$ according to the relation $\left(D^{*} O^{-}=f D_{O^{--}}\right), \alpha$ is ionic charge of the defects responsible of the transport processes

$$
\alpha=\left(\sigma \mathrm{kT} / \mathrm{e}^{2} \mathrm{n}_{\mathrm{O}^{--}} \mathrm{DO}^{--}\right)^{1 / 2}
$$

Using the experimental values of $\sigma$ and $\mathrm{D}^{*} \mathrm{O}=\mathrm{f} \mathrm{D}_{\mathrm{O}^{--}}$, one obtains $\alpha \sim 2$ in the high temperature range $\mathrm{T}>560^{\circ} \mathrm{C}$ and $\alpha \sim 1$ for $\mathrm{T}<560^{\circ} \mathrm{C}$.

These results confirm the hypothesis of isolated vacancy $\left(\mathrm{V}_{\mathrm{O}}^{\circ \circ}\right)$ at high temperature and of complex defect $\left(\mathrm{Y}^{\prime} \mathrm{zr}, \mathrm{Vo}^{\circ)^{\circ}}\right.$ at low temperature. This analysis is consistent with the results obtained for both the high (17.5 moles $\% \mathrm{Y}_{2} \mathrm{O}_{3}$ ) and less ( 3 moles $\% \mathrm{Y}_{2} \mathrm{O}_{3}$ ) doped samples.

The formation of complex defects is favourised at low temperature and high concentration defect. Indeed, for the samples doped with 17.5 moles \%, the concentration of oxygen vacancy $\left(\mathrm{Vo}^{\circ \circ}\right)$ and of $\left(\mathrm{Y}^{\prime} \mathrm{zr}\right)$ is high, so complex defects prevail in all the temperature range and the activation energy is closed to $\mathrm{E}_{\mathrm{b}}$. For the less doped samples $\left(3\right.$ moles $\% \mathrm{Y}_{2} \mathrm{O}_{3}$ ), the concentration of oxygen vacancy is not enough to lead to the formation of complex defects, so isolated vacancies prevail and the activation energy is constant in all the temperature range and closed to $\mathrm{E}_{\mathrm{a}}$.

\section{B- Polycrystals}

According to the previous results, the influence of the microstructure on the electrical conductivity and the composite effect have been studied with polycrystalline samples doped with 9.9 moles $\% \quad \mathrm{Y}_{2} \mathrm{O}_{3}$ and in presence of different amount of alumina.

\section{$\underline{B}_{1}-$ Yttrium doped zirconia polycrystal : $\left(\mathrm{ZrO}_{2}+9.9\right.$ moles $\left.\% \underline{\mathrm{Y}}_{2} \underline{\mathrm{O}}_{3}\right)$}

\section{a- Sample characterization}

The density of the sintered material has been found equal to $84 \%$ of the theoretical density. SEM observations show that the sample is composed of submicronic grains, whose mean size is closed to 0.77 $\mu \mathrm{m}$. X-Ray diffraction analysis have allowed us to identify the cubic solid solution of zirconia doped with 9.9 moles $\% \mathrm{Y}_{2} \mathrm{O}_{3}(\mathrm{a}=5.1400 \AA)$.

b- Electrical conductivity measurements

The results obtained with the polycrystals (Fig.2)confirm the break in the bulk conductivity. 


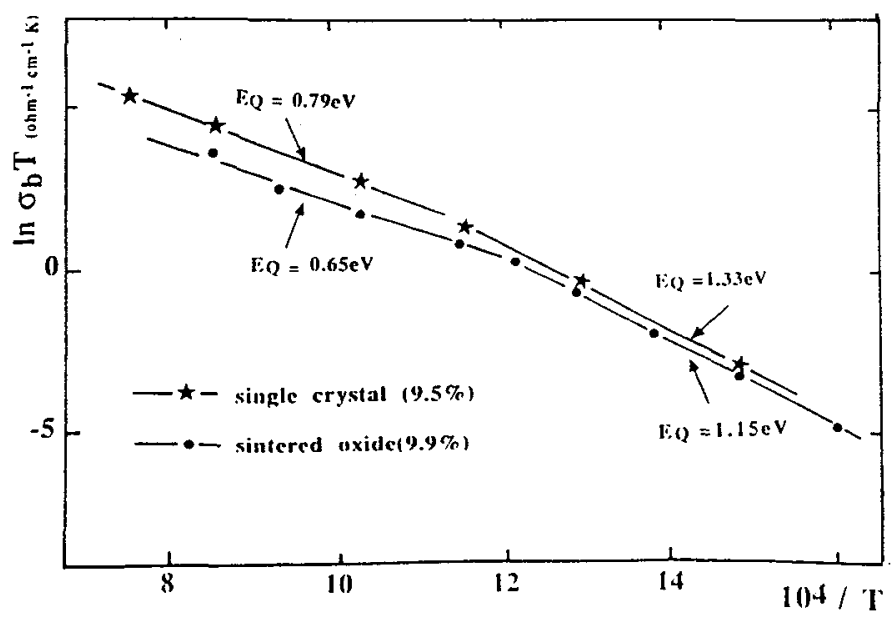

Fig.2: Bulk Conductivity

\section{$\underline{B}_{2}$-Polycrystalline samples of yttrium doped zirconia + alumina (COMPOSITE EFFECT)}

\section{$\left(\left(\mathrm{ZrO}_{2}+9.9\right.\right.$ moles $\left.\% \mathrm{Y}_{2} \underline{\mathrm{O}}_{3}\right)+\mathrm{y}$ moles $\left.\% \mathrm{Al}_{2} \underline{\mathrm{O}_{3}}\right)$}

$$
(y=1,2,5,10 \text { and } 20)
$$

The composite effect leads to an increase of the electrical conductivity. This is due to an increase of the point defect concentration at the interface level between the insulating and the ionic conducting phases(11-13). This effect increase with the decrease of both the temperature and of the grain size of the isolating phase.

\section{a-Characterization}

The density of the different samples is between 91 and $92 \%$ of the theoretical density. The grains size is generally lower than one micron. Nevertheless, a microprobe analysis has allowed us to show a non uniform repartition of the alumina and the presence of aggregates of some microns. As previously, a X-Ray diffraction analysis has allowed us to identify the cubic solid solution of zirconia doped with 9.9 moles \% $\mathrm{Y}_{2} \mathrm{O}_{3}$ in presence of dissolved alumina $(\mathrm{a}=5.1375 \AA$. $)$

\section{b- Electrical conductivity measurements}

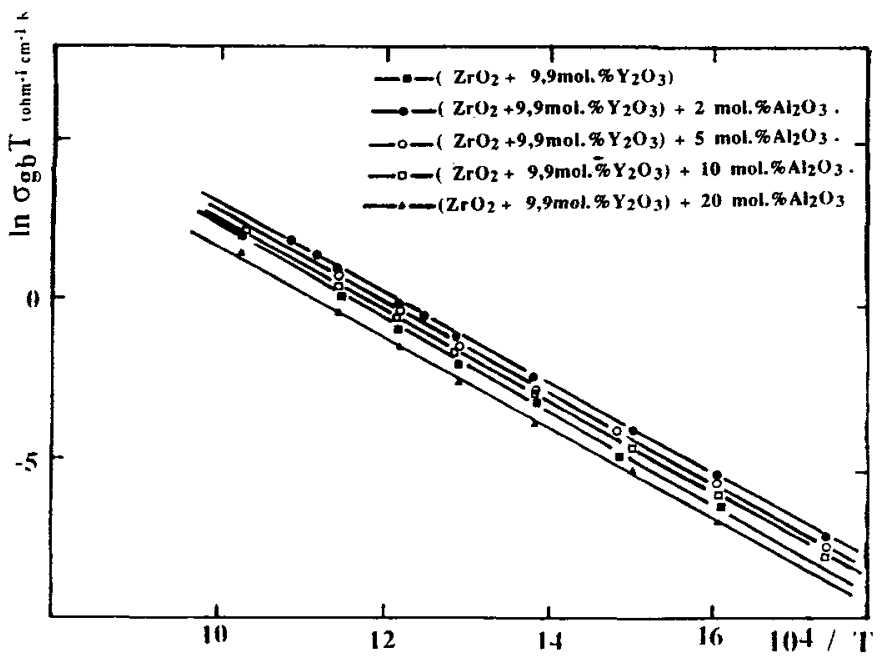

Fig.3: Grain Boundary Conductivity 


\begin{tabular}{|c|c|c|c|c|c|}
\hline & $\begin{array}{c}\mathrm{ZOO}_{2} \\
+9.9 \mathrm{~mol} . \mathrm{W}_{2} \mathrm{O}_{3} \\
\end{array}$ & $\begin{array}{c}\mathrm{ZrO}_{2}+9.9 \mathrm{~mol}^{2} \% \mathrm{Y}_{2} \mathrm{O}_{3} \\
+2 \mathrm{~mol} \% . \mathrm{Al}_{2} \mathrm{O}_{3}\end{array}$ & $\begin{array}{c}\mathrm{ZrO}_{2}+9.9 \mathrm{~mol} \% \mathrm{Y}_{2} \mathrm{O}_{3} \\
+5 \mathrm{~mol} \% . \mathrm{Al}_{2} \mathrm{O}_{3}\end{array}$ & $\begin{array}{l}\mathrm{ZrO}_{2}+9.9 \mathrm{~mol} . \mathrm{FY}_{2} \mathrm{O}_{3} \\
+10 \mathrm{~mol} \% . \mathrm{Al}_{2} \mathrm{O}_{3}\end{array}$ & $\begin{array}{l}\mathrm{ZrO}_{2}+9.9 \mathrm{~mol} . \mathrm{sY}_{2} \mathrm{O}_{3} \\
+20 . \mathrm{mol} \% . \mathrm{Al}_{2} \mathrm{O}_{3}\end{array}$ \\
\hline $\begin{array}{l}\text { activation } \\
\text { energies } \\
(\mathrm{eV})\end{array}$ & 1.251 & 1.210 & 1.200 & 1.228 & 1.206 \\
\hline
\end{tabular}

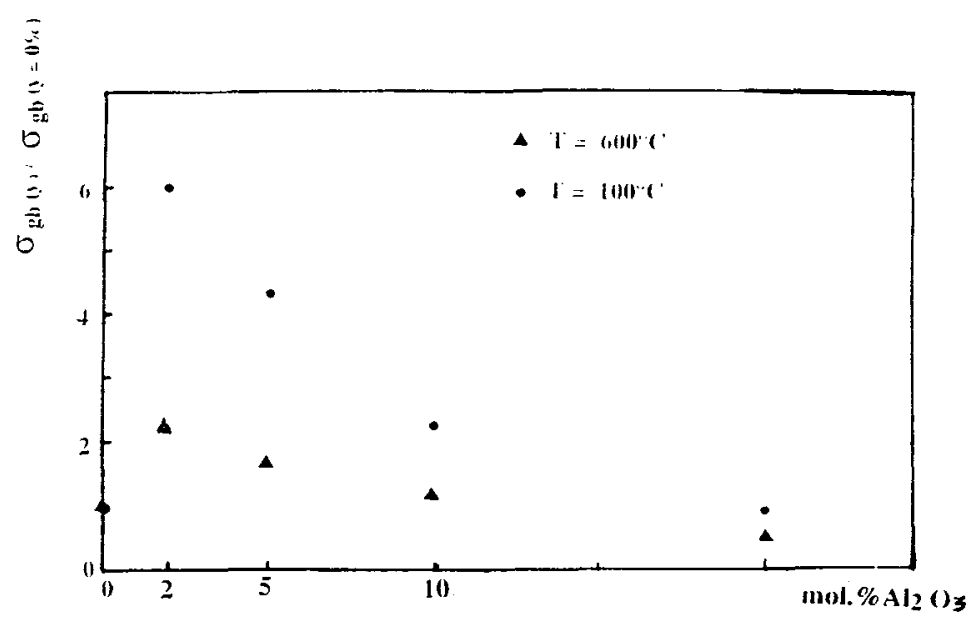

Fig 4

The results show that the grain boudary conductivity increases in presence of aiumina. A maximum of conductivity is observed around $\mathrm{y}=2$ moles $\%$. This effect is a decreasing function of the temperature. The ratio $\sigma \mathrm{gb}(\mathrm{y}=2) / \sigma \mathrm{gb}(\mathrm{y}=0)=2.2$ at $\mathrm{T}=600^{\circ} \mathrm{C} \quad \sigma \mathrm{gb}(\mathrm{y}=2) / \sigma \mathrm{gb}(\mathrm{y}=0)=6$ at $\mathrm{T}=100^{\circ} \mathrm{C}$

\section{CONCLUSION}

The coupling of the electrical conductivity results and of the oxygen diffusion data has allowed to propose two kinds of defect depending of the temperature range and the amount of $\mathrm{Y}_{2} \mathrm{O}_{3}$.Furthermore, we have shown the benefical effect of the alumina on the electrical conductivity at low temperature.

\section{REEERENCES}

(1) J.E Bauerle and J hrizo. J Phys.Chem.Solids 30 (1969) 565.

(2) TH Etsell and S.N.Flengas,Chem.Rev. 70.339 (1970).

(3) E.Shouler, M Kleitz. and C Deportes. J Chim.Phys.(PARIS) 701309 (1973).

(4) P.AbelardJ.F.Baumard. The Am.Phys.Soc. Vol (26) 1005-17 (1982).

(5) S.Badwal, J of Mat.Science $191767-76$ (1984).

(6) A. Barhmi , thesis. I.N.P.G .Grenoble (1987) .

(7) R.Z. Fernandes, thesis .I.N.P.G. .Grenoble (1988)

(8) H. Solmon, thesis .ParisXI (1992)

(9) J.de D.Solier.M.A.Perez.Jubindo,A.Dominguez.Rodriguez,A.H.Heuer. J.Am.Ceram.Soc. , 72 (8) 1500-502 (1989).

(10) W.C.Mackrodt,P.M.Wrodrow. J.Am.Ceram.Soc. 69 (3) 277-80 (1986).

(11) T JOW and J.B. WAGNER, Jr,J.Electrochem.Soc. 126.1963 (1979)

(12) J.MAIER.J.Electrochem.Soc.,134.1524 (1987)

(13) J.MAIER.J.Phys.Chem of Solids.46.309 (1985) 